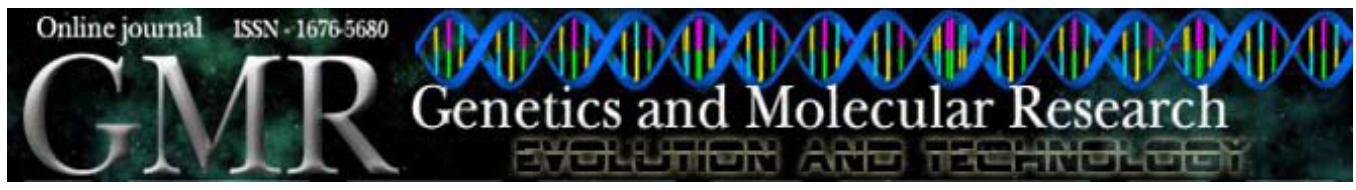

\title{
Genetic diversity of wild and domesticated stocks of Thai abalone, Haliotis asinina (Haliotidae), analyzed by single-strand conformational polymorphism of AFLP-derived markers
}

\author{
P. Praipue ${ }^{1}$, S. Klinbunga ${ }^{2,3}$ and P. Jarayabhand ${ }^{4,5}$ \\ 'Program in Biotechnology, Faculty of Science, \\ Chulalongkorn University, Bangkok, Thailand \\ ${ }^{2}$ Aquatic Molecular Genetics and Biotechnology Laboratory, \\ National Center for Genetic Engineering and Biotechnology, \\ National Science and Technology Development Agency, \\ Klong Luang, Pathumthani, Thailand \\ ${ }^{3}$ Center of Excellence for Marine Biotechnology, \\ Faculty of Science, Chulalongkorn University, Bangkok, Thailand \\ ${ }^{4}$ Department of Marine Science, Faculty of Science, \\ Chulalongkorn University, Bangkok, Thailand \\ ${ }^{5}$ Aquatic Resources Research Institute, Chulalongkorn University, \\ Bangkok, Thailand
}

Corresponding author: S. Klinbunga

E-mail: sirawut@biotec.or.th

Genet. Mol. Res. 9 (2): 1136-1152 (2010)

Received February 24, 2010

Accepted March 22, 2010

Published June 15, 2010

DOI 10.4238/vol9-2gmr808

\begin{abstract}
Amplified fragment length polymorphism (AFLP) analysis was carried out on representative individuals of wild Haliotis asinina using 64 primer combinations. Nine polymorphic AFLPs were cloned and sequenced. Sequence-specific primers were designed from six AFLP-derived fragments. Three sequence-characterized amplified region (SCAR) markers $\left(\mathrm{HaSCAR}_{320}, \mathrm{HaSCAR}_{295}, \mathrm{HaSCAR}_{327}\right)$ were selected for genotyping of 8-month-old domesticated stocks of $H$. asinina cultured separately at Sichang Marine Science Research and
\end{abstract}


Training Station $(\mathrm{N}=95)$ and at a hatchery in Trang province $(\mathrm{N}=40)$ using single-strand conformational polymorphism analysis. Genotypes of wild abalone originating from Talibong Island $(\mathrm{N}=25)$, Cambodia $(\mathrm{N}=22)$, and the $\mathrm{P}_{0}$ progeny established from Samet Island founders $(\mathrm{N}=20)$ were also investigated. Significant genetic differentiation $(\mathrm{P}<$ 0.0001 for the exact test and $\left.F_{\mathrm{ST}}=0.8759-0.8919, \mathrm{P}<0.001\right)$ between abalone from the Gulf of Thailand (Cambodia and Samet Island - east) and the Andaman Sea (Talibong Island - west) were observed. This demonstrated the strong biogeographic structure of $H$. asinina in Thai waters. Non-overlapping composite genotypes for wild abalone from different coastal regions allow us to determine founder contributions in domesticated abalone stocks. Almost all Sichang Marine Science Research and Training Station and the Trang province hatchery stocks exhibited the east coast genotypes ( $97 \%$ of the 135 samples). We suggest that abalone from the east coast population have better survival rates under cultivated conditions than those from the west coast population.

Key words: AFLP; SSCP; Abalone; Genetic diversity; Domestication; Stock identification

\section{INTRODUCTION}

Abalone are marine gastropods distributed worldwide along temperate and tropical coastal areas (Geiger, 2000). Fifty-seven extant species are recognized and over 15 species, mainly the temperate species, are farmed and commercially important (Jarayabhand and Paphavasit, 1996; Evans et al., 2001). The total world production of abalone was approximately 22,000 metric tons in 2002. Of which, 8696 metric tons were from aquaculture (Gordon and Cook, 2004).

In Thailand, three species of tropical abalone: Haliotis asinina, Linnaeus, H. ovina, Gmelin and H. varia, Linneaus, are found in Thai waters (Jarayabhand and Paphavasit, 1996). Among these abalone, $H$. asinina provides the highest percentage $(85 \%)$ of meat weight to total weight compared to that of H. ovina (40\%) and H. varia (30\%) (Singhagraiwan and Doi, 1993). Therefore, $H$. asinina has a high value for the "cocktail-sized" (40-70 $\mathrm{mm}$ ) abalone market, as is true for H. diversicolor supertexta in Taiwan (Jarayabhand and Paphavasit, 1996).

Artificially propagated breeding programs and culture techniques for $H$. asinina are well developed. More importantly, $H$. asinina is a year-round spawning species. The spawning cycle is highly predictable. Therefore, $H$. asinina is the target species for the culture industry in Thailand (Selvamani et al., 2000; Klinbunga et al., 2004; Tang et al., 2004).

The basic information on genetic population differentiation and levels of genetic diversity of $H$. asinina in Thai waters is necessary to improve the stock selection program and establish an effective selective breeding program for this species (Klinbunga et al., 2003). In addition, molecular genetic markers that can be applied for genetic management in wild and domesticated stocks of $H$. asinina are also required.

Klinbunga et al. (2003) examined genetic diversity of $H$. asinina originating from Samet Island and Cambodia (east), and Trang (west) by polymerase chain reaction-restriction fragment length polymorphism (PCR-RFLP) of $18 S$ and $16 S$ rDNAs. Restriction analysis of $18 S$ rDNA 
(nuclear) with AluI, TaqI, and HaeIII and $16 S$ rDNA (mitochondrial) with BamHI, EcoRI, HaeIII, and $A l u$ I gave 12 and 13 digestion patterns, respectively. A total of 49 composite haplotypes were obtained from all single haplotypes. Geographic heterogeneity and $F_{\mathrm{ST}}$ analyses did not reveal genetic differentiation between $H$. asinina originating from the Andaman Sea (west) and the Gulf of Thailand (east, $\mathrm{P}>0.05$ ) suggesting the panmictic gene pool of Thai $H$. asinina. The lack of genetic heterogeneity of $H$. asinina in Thai waters should be confirmed by other genetic markers.

The breeding program of $H$. asinina at Sichang Marine Science Research and Training Station (SMaRT), Chulalongkorn University, has been carried out for more than a decade. Founders of the established stocks were originated from various geographic locations of both the Gulf of Thailand (east) and the Andaman Sea (west). As a result, levels of genetic diversity and patterns of gene pools of the present domesticated stocks should be examined by appropriate genetic markers to reveal possible changes in variability caused by genetic drift, inbreeding, or selection (Allendorf and Ryman, 1987; Cruz et al., 2004).

Amplified fragment length polymorphism (AFLP) analysis (Vos et al., 1995) is a PCR-based multilocus fingerprinting technique that combines the strengths and overcomes the weaknesses of PCR-RFLP and random amplified polymorphic DNA (RAPD)-PCR (Williams et al., 1990). AFLP analysis has been used for indirect examination of levels of genetic diversity in several species (Li et al., 2006; Khamnamtong et al., 2006; Yu and Chu, 2006; Zhang et al., 2007; Gruenthal and Burton, 2008; Zhao et al., 2009).

The major strengths of the AFLP method include simultaneous screening of a large number of polymorphic loci, high reproducibility due to high stringency of PCR, and relative cost effectiveness (Lui and Cordes, 2004). Moreover, it does not require any prior molecular information about sequences under investigation and is thus especially applicable to species in which the genome sequences are not well characterized, like $H$. asinina. More important, taxonomically specific fragments and/or polymorphic fragments can be converted to sequencecharacterized amplified region (SCAR) markers for different applications (Khamnamtong et al., 2006; Klinbunga et al., 2007).

Recently, single-strand conformational polymorphism (SSCP) has been applied for examining genetic diversity in various species (Orita et al., 1989; Khamnamtong et al., 2005; Klinbunga et al., 2006). The major advantage of SSCP is that variations differing by one or a few substitutions could be detected (Orita et al., 1989). Therefore, SSCP is one of the potential techniques for detection of genetic polymorphism at different taxonomic levels.

The objective of this study was to develop polymorphic molecular markers derived from candidate population-specific AFLPs. SSCP was further carried out to reveal geographic differentiation of wild abalone and subsequently, to examine genetic diversity, the pattern of gene pools and stock origin of domesticated H. asinina. Different contribution levels of founders from the Andaman Sea and the Gulf of Thailand to the present domesticated stocks were found and reported for the first time in this species.

\section{MATERIAL AND METHODS}

\section{Samples}

Wild specimens of $H$. asinina were collected from Talibong Island, Trang province (TRGW, $\mathrm{N}=25$ ) located in the Andaman Sea and Cambodia (CAME, $\mathrm{N}=22$ ) located in the 
Gulf of Thailand. The $\mathrm{P}_{0}$ progeny established from founders originating from Samet Island, Rayong province (SAME, $\mathrm{N}=20$ ) were also included for population genetic studies (Figure 1). Moreover, the 6th-generation progeny (8 months old) cultured separately at Sichang Marine Science Research and Training Station $(\mathrm{CSMaRTH}, \mathrm{N}=95)$ and at a hatchery in Trang province (CTRGH, $\mathrm{N}=40$ ) were also collected (Table 1). The domesticated stocks were established from approximately 200 founders, originating from both coastal sides of the Thai peninsula, by mass spawning. Closed life cycle breeding has been carried out for subsequent generations by random mating to avoid effects of inbreeding depression of the propagated stocks. Foot tissue or epipodial tentacles were dissected and kept at $-30^{\circ} \mathrm{C}$ or in absolute ethanol until needed.

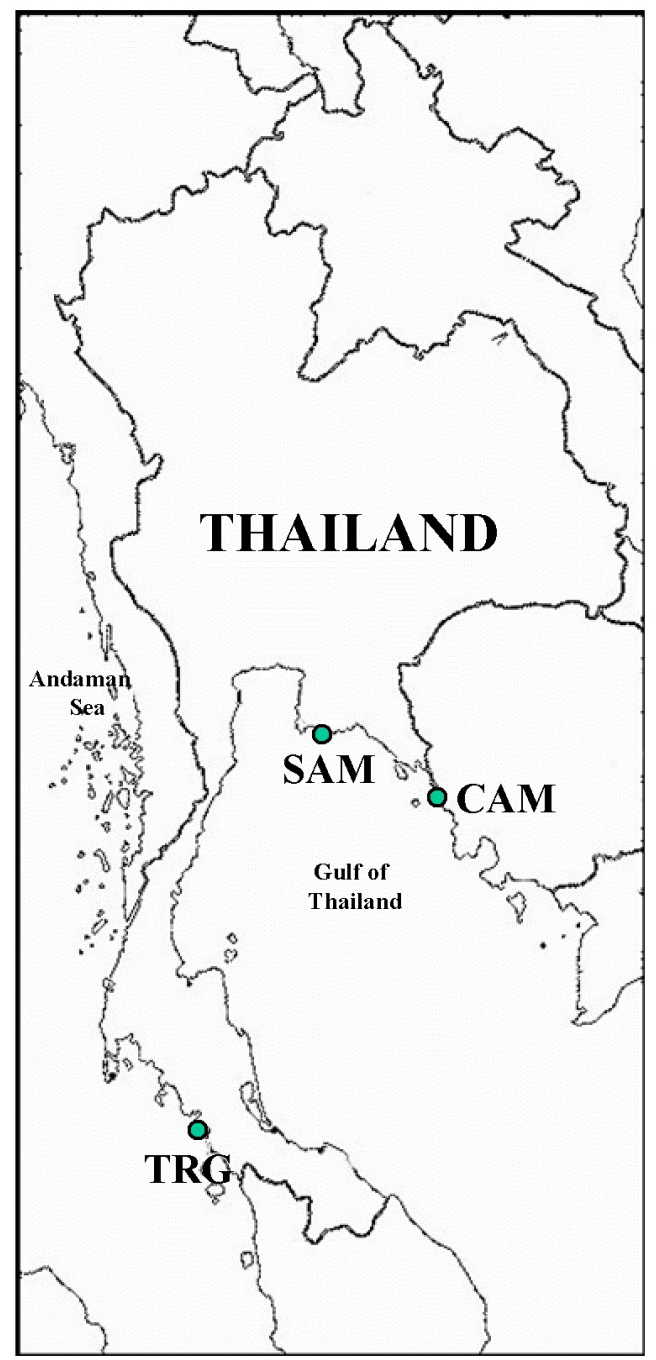

Figure 1. Map of Thailand indicating sampling sites of wild Haliotis asinina used in this study. Dots represent sample locations from which $H$. asinina was collected. $\mathrm{CAM}=$ Cambodia, $\mathrm{SAM}=$ Samet Island, $\mathrm{TRG}=$ Trang . 


\begin{tabular}{|c|c|c|}
\hline Geographic origin & Abbreviation & Sample size $(\mathrm{N})$ \\
\hline \multicolumn{3}{|l|}{ Wild stocks } \\
\hline Talibong Island, Trang (Andaman Sea) & TRGW & 25 \\
\hline Cambodia (east of peninsular Thailand) & CAME & 22 \\
\hline $\mathrm{P}_{0}$ stock, Samet Island, Rayong (Gulf of Thailand) & SAME & 20 \\
\hline \multicolumn{3}{|l|}{ Domesticated stocks } \\
\hline Trang hatchery & CTRGH & 40 \\
\hline Sichang Marine Science Research and Training Station, Chonburi & CSMaRTH & 95 \\
\hline Total & & 202 \\
\hline
\end{tabular}

\section{DNA extraction}

Genomic DNA was extracted from each abalone using a phenol-chloroform-proteinase $\mathrm{K}$ extraction method (Klinbunga et al., 2003). The concentration of extracted DNA was spectrophotometrically determined and kept at $4^{\circ} \mathrm{C}$ until needed.

\section{AFLP analysis}

AFLP analysis was carried out according to a standard protocol (Vos et al., 1995). Briefly, genomic DNA (250 ng) of two individuals each from TRGW and SAME was digested with EcoRI and MseI before ligation with restriction site-specific adaptors. Preamplification was carried out utilizing adaptor-specific primers with a single selective base (boldfaced and

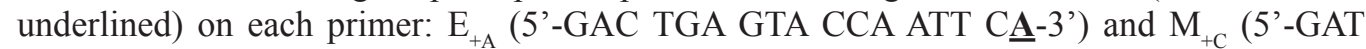
GAG TCC TGA GTAAC-3'). The preamplification product was diluted 5-fold and selectively amplified with 64 primer combinations $\left(\mathrm{E}_{+\mathrm{ANN}}\right.$ and $\mathrm{M}_{+\mathrm{CNN}}$, Table 2), 1.5 units of DyNazyme II DNA Polymerase (Finnzymes), and $1 \mu \mathrm{L}$ of the diluted preamplification product. PCR was performed with 2 cycles of denaturation at $94^{\circ} \mathrm{C}$ for $45 \mathrm{~s}$, annealing at $65^{\circ} \mathrm{C}$ for $60 \mathrm{~s}$, and extension at $72^{\circ} \mathrm{C}$ for $90 \mathrm{~s}$, followed by 12 cycles of a touchdown phase where the annealing temperature was lowered $1^{\circ} \mathrm{C}$ after every cycle and additional 25 cycles of $94^{\circ} \mathrm{C}$ for $45 \mathrm{~s}, 53^{\circ} \mathrm{C}$ for $60 \mathrm{~s}$, and $72^{\circ} \mathrm{C}$ for $90 \mathrm{~s}$. The final extension was carried out at $72^{\circ} \mathrm{C}$ for $5 \mathrm{~min}$. AFLPs were size-fractionated by $4.5-5.0 \%$ denaturing polyacrylamide gels and visualized by silver staining (Sambrook and Russell, 2001).

Table 2. Primer combinations used for screening of amplified fragment length polymorphisms in Haliotis asinina.

\begin{tabular}{|c|c|c|c|c|c|c|c|c|}
\hline & $\mathrm{E}_{\mathrm{AAG}}$ & $\mathrm{E}_{\mathrm{ACA}}$ & $\mathrm{E}_{\mathrm{ACC}}$ & $\mathrm{E}_{\mathrm{AGG}}$ & $\mathrm{E}_{\mathrm{AGA}}$ & $\mathrm{E}_{\mathrm{ATG}}$ & $\mathrm{E}_{\mathrm{ATC}}$ & $\mathrm{E}_{\mathrm{ATA}}$ \\
\hline$\overline{\mathrm{M}_{\mathrm{CAC}}}$ & + & + & - & + & + & + & + & + \\
\hline $\mathrm{M}_{\mathrm{CAG}}^{\mathrm{CAC}}$ & + & + & - & + & + & - & + & - \\
\hline $\mathrm{M}_{\text {CTA }}^{\text {CAG }}$ & + & + & - & + & + & + & + & + \\
\hline $\mathrm{M}_{\mathrm{CTG}}$ & + & + & - & + & + & - & + & - \\
\hline $\mathrm{M}_{\mathrm{CTT}}$ & + & + & - & + & + & + & + & + \\
\hline $\mathrm{M}_{\mathrm{CGA}}$ & + & + & - & + & + & + & + & - \\
\hline $\mathrm{M}_{\mathrm{CGA}}^{\mathrm{CGA}}$ & + & - & - & + & - & - & + & - \\
\hline $\mathrm{M}_{\mathrm{CGC}}$ & + & - & - & + & + & - & + & - \\
\hline $\mathrm{M}_{\mathrm{CGG}}$ & + & - & + & - & + & - & + & - \\
\hline $\mathrm{M}_{\mathrm{CCA}}^{\mathrm{CGG}}$ & + & - & + & - & + & + & + & - \\
\hline $\mathrm{M}_{\mathrm{CCT}}^{\mathrm{CA}}$ & + & - & + & - & + & + & + & - \\
\hline $\mathrm{M}_{\mathrm{CCG}}^{\mathrm{CTT}}$ & + & - & + & - & - & + & + & - \\
\hline $\mathrm{M}_{\mathrm{CCC}}$ & - & - & - & - & - & + & + & - \\
\hline
\end{tabular}




\section{Cloning and sequencing of AFLPs}

Nine polymorphic AFLPs were excised from the gels. The eluted PCR product was reamplified by the original primers. The target band was ligated to pGEM-T Easy vector (Promega) and transformed into Escherichia coli JM109. Plasmid DNA was extracted and sequenced for both directions. The nucleotide sequence of an AFLPderived fragment was compared with those previously deposited in the GenBank using Blast $N$ and Blast $X$ (Altschul et al., 1990, available at http://www.ncbi/nlm/nih.gov). Significant probabilities of matched nucleotides and proteins were considered when the $E$-value was $<10^{-4}$.

\section{Development of SCAR markers and SSCP analysis}

Sequence-specific primers were designed from six AFLP-derived markers (Table 3). The amplification reaction was carried out on the genomic DNA of each abalone in a $15-\mu \mathrm{L}$ reaction volume containing $10 \mathrm{mM}$ Tris- $\mathrm{HCl}, \mathrm{pH} 8.3,50 \mathrm{mM} \mathrm{KCl}, 1.5 \mathrm{mM}$ $\mathrm{MgCl}_{2}, 200 \mu \mathrm{M}$ of each dNTP, $0.4 \mu \mathrm{M}$ of each primer, 1 unit DyNazyme II DNA Polymerase (Finnzymes) and $50 \mathrm{ng}$ genomic DNA. PCR was performed by predenaturation at $94^{\circ} \mathrm{C}$ for $3 \mathrm{~min}$, followed by 10 cycles of $94^{\circ} \mathrm{C}$ for $45 \mathrm{~s}$, at $10^{\circ} \mathrm{C}$ above the annealing temperature of each primer pair for 1 min (Table 2), with a reduction of $2^{\circ} \mathrm{C}$ every other cycle and extension at $72^{\circ} \mathrm{C}$ for $45 \mathrm{~s}$, and 30 cycles of $94^{\circ} \mathrm{C}$ for $45 \mathrm{~s}$, at the appropriate annealing temperature for $1 \mathrm{~min}$ (Table 3 ) and $72^{\circ} \mathrm{C}$ for $45 \mathrm{~s}$. The final extension was carried out at $72^{\circ} \mathrm{C}$ for $10 \mathrm{~min}$. The PCR product was electrophoretically analyzed through $1.5 \%$ agarose gels visualized under a transilluminator after ethidium bromide staining. Sizes of products were determined by comparing with a $100 \mathrm{bp}$-marker.

Table 3. Blast analysis, primer sequence, annealing temperature (Ta), and the expected product size of amplified fragment length polymorphism (AFLP)-derived sequence-characterized amplified region (SCAR) markers of Haliotis asinina.

\begin{tabular}{|c|c|c|c|c|c|c|}
\hline AFLP primers & $\begin{array}{c}\text { Size of } \\
\text { fragment (bp) }\end{array}$ & $\begin{array}{c}\text { Blast } \\
\text { analysis }\end{array}$ & $\begin{array}{c}\text { Name of } \\
\text { SCAR marker }\end{array}$ & Primer sequence (5'-3') & $\mathrm{Ta}\left({ }^{\circ} \mathrm{C}\right)$ & $\begin{array}{c}\text { Expected } \\
\text { product }(b p)\end{array}$ \\
\hline $\mathrm{E}_{\mathrm{AGA}} / \mathrm{M}_{\mathrm{CGC}}$ & 345 & Unknown & $\mathrm{HaSCAR}_{328}$ & $\begin{array}{l}\text { F: TACGAATTCAGACTACACGCAA } \\
\text { R: GATTAACGCTCTCAATGAGAGA }\end{array}$ & 57 & 328 \\
\hline $\mathrm{E}_{\mathrm{AGA}} / \mathrm{M}_{\mathrm{CCA}}$ & 380 & Unknown & $\mathrm{HaSCAR}_{167}$ & $\begin{array}{l}\text { F: GCTCTCACATTGTAGCCTTTG } \\
\text { R: ATTGAAATGGAAAGAAAAGTG }\end{array}$ & 50 & 167 \\
\hline $\mathrm{E}_{\mathrm{ATC}} / \mathrm{M}_{\mathrm{CAG}}$ & 356 & Unknown & $\mathrm{HaSCAR}_{339}$ & $\begin{array}{l}\text { F: TACGAATTCATCAAAGGGAC } \\
\text { R: GATTAACAGACTGCTGCCCA }\end{array}$ & 57 & 339 \\
\hline $\mathbf{E}_{\mathrm{ATC}} / \mathbf{M}_{\mathrm{CTT}}$ & 351 & Unknown & HaSCAR $_{320}$ & $\begin{array}{l}\text { F: TACGAATTCATCCTCGATAGTC } \\
\text { R: GATTAACTTGGCAACAAGTGA }\end{array}$ & 50 & 320 \\
\hline $\mathbf{E}_{\mathrm{ATC}} / \mathbf{M}_{\mathrm{CGT}}$ & 336 & Unknown & HaSCAR $_{295}$ & $\begin{array}{l}\text { F: TACGAATTCATCGCTCTAATCAT } \\
\text { R: AACAGACCGGAACTCTCATG }\end{array}$ & 55 & 295 \\
\hline $\mathbf{E}_{\mathrm{ATC}} / \mathbf{M}_{\mathrm{CCC}}$ & 344 & Unknown & HaSCAR $_{327}$ & $\begin{array}{l}\text { F: TACGAATTCATCCAACAAAGG } \\
\text { R: GATTAACCCTAACCTATCGTAAA }\end{array}$ & 50 & 327 \\
\hline $\begin{array}{l}\mathrm{E}_{\mathrm{ATG}} / \mathrm{M}_{\mathrm{CCG}} \\
\mathrm{E}_{\mathrm{ATC}} / \mathrm{M}_{\mathrm{CGC}}\end{array}$ & $\begin{array}{l}164 \\
102\end{array}$ & $\begin{array}{l}\text { Unknown } \\
\text { Unknown }\end{array}$ & $\begin{array}{l}\text { ND } \\
\text { ND }\end{array}$ & $\begin{array}{l}\text { ND } \\
\text { ND }\end{array}$ & $\begin{array}{l}\mathrm{ND} \\
\mathrm{ND}\end{array}$ & $\begin{array}{l}\text { ND } \\
\text { ND }\end{array}$ \\
\hline $\mathrm{E}_{\mathrm{ATC}} / \mathrm{M}_{\mathrm{CGG}}$ & 127 & Unknown & $\mathrm{ND}$ & ND & ND & ND \\
\hline
\end{tabular}

*ND $=$ not determined. SCAR markers further used for single-strand conformational polymorphism analysis are boldfaced. 
For SSCP analysis, the amplification product of each specimen $(6 \mu \mathrm{L})$ was mixed with 4 volume of the loading dye ( $95 \%$ formamide, $0.25 \%$ bromophenol blue, $0.25 \%$ xylene cyanol and $10 \mathrm{mM} \mathrm{NaOH}$ ). The mixture was then denatured at $95^{\circ} \mathrm{C}$ for $5 \mathrm{~min}$, and immediately placed on ice for at least $3 \mathrm{~min}$. Non-denaturing polyacrylamide gel (12.5-17.5\%; 37.5:1 crosslink) was used for analysis at $12.5 \mathrm{~V} / \mathrm{cm}$ for $16 \mathrm{~h}$ at $4^{\circ} \mathrm{C}$. SSCP patterns were visualized by silver staining. The nucleotide sequence of each SSCP genotype of $\mathrm{HaSCAR}_{320}$, $\mathrm{HaSCAR}_{295}$, $\mathrm{HaSCAR}_{327}$ was direct-sequenced. Nucleotide divergence between sequences was calculated based on the two-parameter method (Kimura, 1980).

\section{Data analysis}

The percentage of monomorphic ( $>95 \%$ of investigated specimens) and polymorphic ( $<95 \%$ of investigated specimens) bands and gene diversity (Nei, 1987) was estimated for each geographic sample. Unbiased genetic distance between pairs of samples was determined (Nei, 1978). Genetic heterogeneity in allele distribution frequencies between geographic samples compared was examined using the exact test. The $F_{\mathrm{ST}}$-based statistics $(\theta)$ between pairs of samples, bootstrapping 10,000 iterations to generate the $95 \%$ confidence interval, was estimated. The $\chi^{2}$ value was calculated and tested to determine whether $\theta$ was statistically different from zero (Weir and Cockerham, 1984) using $\chi^{2}=2 \mathrm{~N} \theta(\mathrm{k}-1)$ and d.f. $=(\mathrm{k}-1)(\mathrm{s}-1)$, where $\mathrm{N}=$ number of investigated individuals, $\mathrm{k}$ $=$ number of alleles per locus and $\mathrm{s}=$ number of geographic samples. Population genetic parameters described above were computationally analyzed by TFPGA (Miller, 1997). The significance level of multiple comparisons was further adjusted using a sequential Bonferroni's method (Rice, 1989).

\section{RESULTS}

\section{Development of AFLP-derived SCAR markers}

All screened primer combinations generated the amplification products (Figure 2). In total, 1128 bands ranging from 100-600 bp in size were found and $462(40.96 \%)$ of which were polymorphic. Of these, 166 and 174 bands were only observed in representative individuals of TRGW or SAME, respectively.

Four candidate population-specific AFLPs for TRGW and SAME and one polymorphic AFLP were converted to SCAR markers. Nucleotide sequences of cloned fragments did not match any previously deposited sequence in the GenBank ( $E$-value $\left.>10^{-4}\right)$ and were regarded as non-coding DNA segments in the $H$. asinina genome (Figure 3). A pair of primers was designed from $\mathrm{E}_{\mathrm{AGA}} / \mathrm{M}_{\mathrm{CGC}}-345, \mathrm{E}_{\mathrm{AGA}} / \mathrm{M}_{\mathrm{CCA}}-380, \mathrm{E}_{\mathrm{ATC}} / \mathrm{M}_{\mathrm{CAG}}-356, \mathrm{E}_{\mathrm{ATC}} /$ $\mathrm{M}_{\mathrm{CTT}}-351, \mathrm{E}_{\mathrm{ATC}} / \mathrm{M}_{\mathrm{CGT}}-336$, and $\mathrm{E}_{\mathrm{ATC}} / \mathrm{M}_{\mathrm{CCC}}-344$ (hereafter called HaSCAR 328 , HaSCAR ${ }_{167}$, HaSCAR $_{339}, \operatorname{HaSCAR}_{320}, \mathrm{HaSCAR}_{295}, \mathrm{HaSCAR}_{327}$, respectively; Table 3) and tested against the genomic DNA of $H$. asinina. All primer pairs generated the positive amplification product (data not shown) but only $\mathrm{HaSCAR}_{320}, \mathrm{HaSCAR}_{295}$ and $\mathrm{HaSCAR}_{327}$ were polymorphic and further tested across wild specimens (CAME and TRGW) and the $\mathrm{P}_{0}$ progeny of the SAME sample by SSCP analysis. 


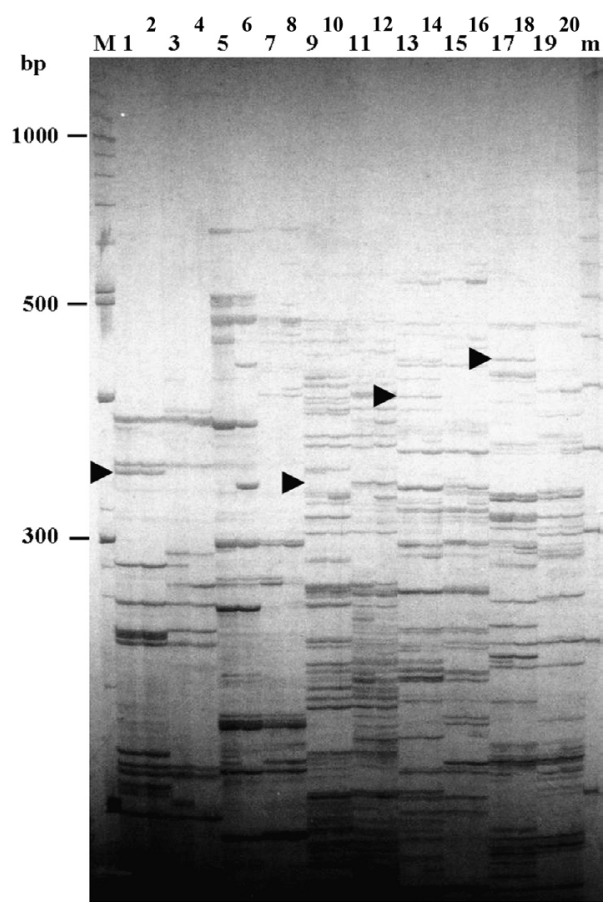

Figure 2. A 4.5\% denaturing polyacrylamide gel electrophoresis showing amplified fragment length polymorphism (AFLP) patterns of five selective primer combinations: $\mathrm{E}_{\mathrm{AAG}} / \mathrm{M}_{\mathrm{CGT}}, \mathrm{E}_{\mathrm{AAG}} / \mathrm{M}_{\mathrm{CGC}}, \mathrm{E}_{\mathrm{AGA}} / \mathrm{M}_{\mathrm{CTA}}, \mathrm{E}_{\mathrm{AGA}} / \mathrm{M}_{\mathrm{CAG}}$, and $\mathrm{E}_{\mathrm{AGA}} /$ $\mathrm{M}_{\mathrm{CTT}}$ corresponding to lanes 1-4, 5-8, 9-12, 13-16, and 17-20, respectively. Arrowheads indicate candidate population-specific AFLP markers. Lanes $M$ and $m$ are 100- and 50-bp DNA markers, respectively.

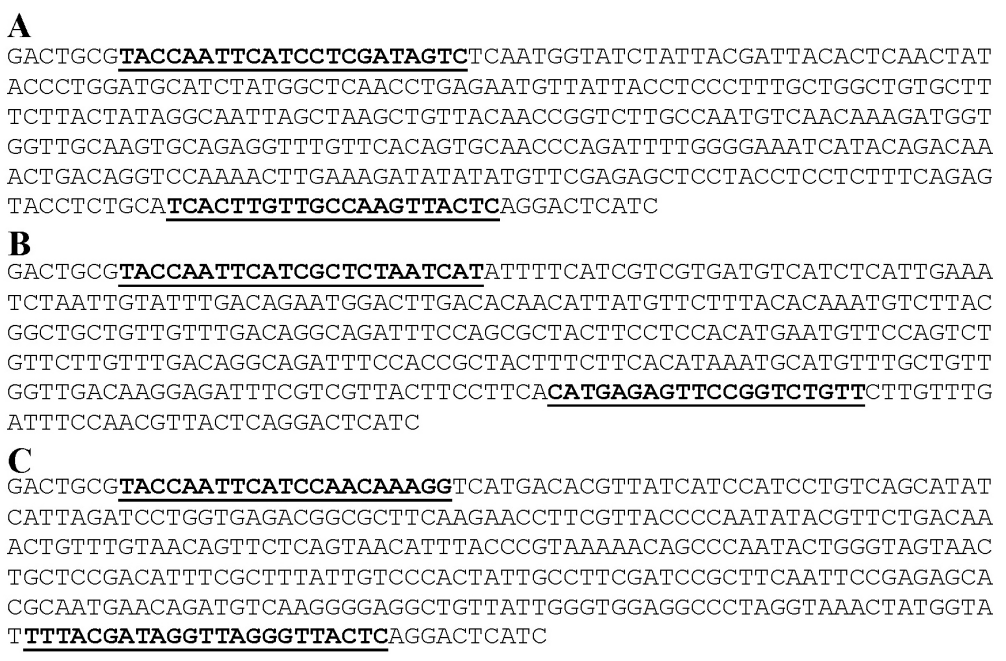

Figure 3. Nucleotide sequence of $\operatorname{HaSCAR}_{320}(\mathrm{~A}), \operatorname{HaSCAR}_{295}(\mathrm{~B})$ and $\operatorname{HaSCAR}_{327}(\mathrm{C})$ derived from $\mathrm{E}_{\mathrm{ATC}} / \mathrm{M}_{\mathrm{CTT}}{ }^{-}$ $351, \mathrm{E}_{\mathrm{ATC}} / \mathrm{M}_{\mathrm{CGT}}-336$ and $\mathrm{E}_{\mathrm{ATC}} / \mathrm{M}_{\mathrm{CCC}}-344$ amplified fragment length polymorphism markers. Positions of the forward and those complementary to the reverse primer of each sequence-characterized amplified region (SCAR) marker are boldfaced and underlined. 


\section{Genetic diversity and intraspecific differentiation of $H$. asinina in Thai waters}

Three, two and three SSCP genotypes were found from the respective SCAR markers (Figure 4). SSCP genotypes between abalone from the Gulf of Thailand and Andaman Sea at the $\mathrm{HaSCAR}_{327}$ locus did not overlap whereas a single individual from the west coast (TRGW) exhibited genotype A at $\mathrm{HaSCAR}_{320}$ and $\mathrm{HaSCAR}_{295}$ loci, which were commonly carried by examined individuals of CAME and SAME samples (Table 4). The nucleotide sequence of the amplified product from an individual exhibiting each SSCP pattern of $\mathrm{HaSCAR}_{320}, \mathrm{HaSCAR}_{295}$ and $\mathrm{HaSCAR}_{327}$ was examined. Different SSCP genotypes of each SCAR marker could be differentiated by at least one single nucleotide polymorphism (Figure 5).

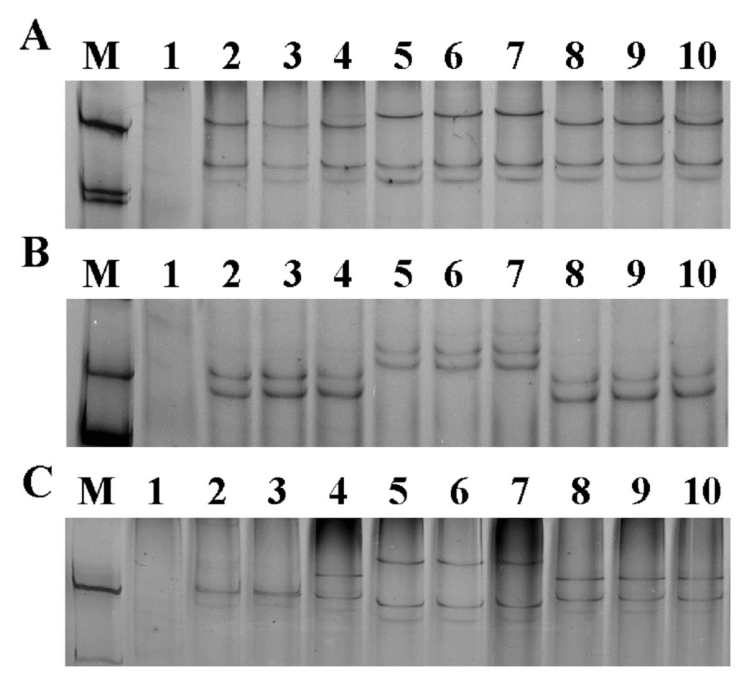

Figure 4. Single-strand conformational polymorphism patterns resulted from $15 \%$ non-denaturing polyacrylamide gel electrophoresis of three sequence-characterized amplified region (SCAR) markers: $\operatorname{HaSCAR}_{320}$ (A), $\mathrm{HaSCAR}_{295}$ (B) and $\mathrm{HaSCAR}_{327}(\mathrm{C})$ of $H$. asinina from the domesticated stocks (genotypes A for HaSCAR ${ }_{320}$ and $\mathrm{HaSCAR}_{295}$, lanes 2-4, and genotypes A, lanes 2, 3, and C, lane 4, for $\mathrm{HaSCAR}_{327}$ ), Talibong Island (lanes 5-7, genotypes B, B and $\mathrm{B}$, respectively), and Cambodia (lanes 8-10, genotypes A, A and C, respectively). Lanes $M$ and 1 are 100-bp DNA ladder and the non-denatured polymerase chain reaction product (double-standard control), respectively.

\begin{tabular}{|c|c|c|c|c|c|c|c|c|}
\hline \multirow[t]{2}{*}{ Sample } & \multicolumn{3}{|c|}{ HaSCAR $_{320}$} & \multicolumn{2}{|c|}{$\mathrm{HaSCAR}_{295}$} & \multicolumn{3}{|c|}{$\mathrm{HaSCAR}_{327}$} \\
\hline & $\mathrm{A}$ & $\mathrm{B}$ & $\mathrm{C}$ & $\mathrm{A}$ & $\mathrm{B}$ & $\mathrm{A}$ & $\mathrm{B}$ & $\mathrm{C}$ \\
\hline SAME & 18 & - & 2 & 20 & - & 18 & - & 2 \\
\hline CAME & 14 & - & 8 & 22 & - & 22 & - & - \\
\hline TRGW & 1 & 24 & - & 1 & 24 & - & 25 & - \\
\hline CTRGH & 32 & - & 8 & 37 & 3 & 25 & 4 & 11 \\
\hline CSMaRTH & 84 & 3 & 8 & 95 & - & 79 & - & 16 \\
\hline Total & 149 & 27 & 26 & 175 & 27 & 144 & 29 & 29 \\
\hline
\end{tabular}




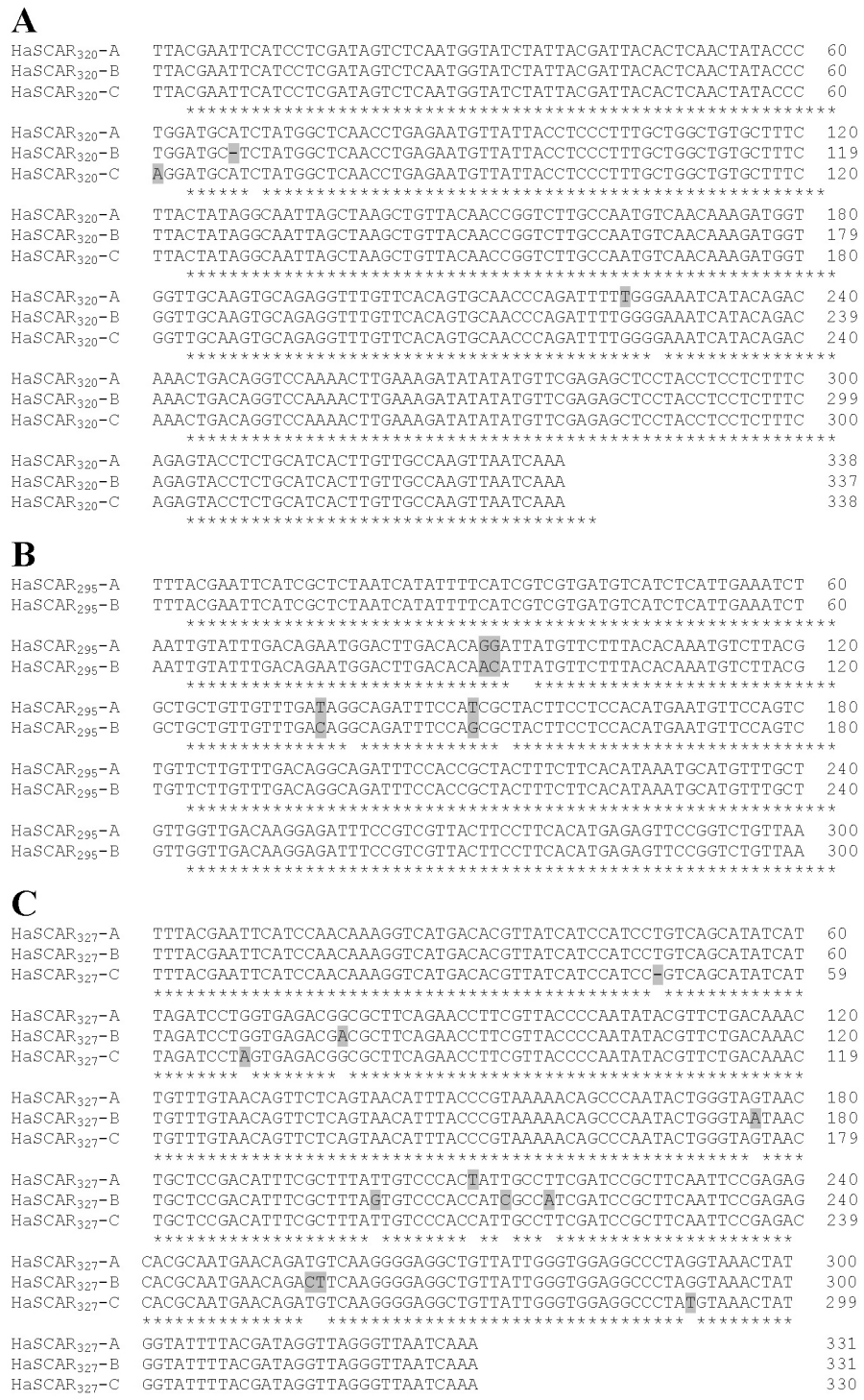

Figure 5. Nucleotide sequence of each single-strand conformational polymorphism genotype of $\operatorname{HaSCAR}_{320}(\mathrm{~A})$, $\mathrm{HaSCAR}_{295}$ (B) and $\mathrm{HaSCAR}_{327}$ (C) sequence-characterized amplified region (SCAR) markers. Asterisks and dashes indicate identical nucleotides and alignment gaps, respectively. Polymorphic nucleotides and indels are highlighted.

Six composite SSCP genotypes were found in wild abalone in this study. AAA, AAC and CAA genotypes were restrictively found in those from the Gulf of Thailand whereas ABB, $\mathrm{BAB}$ and $\mathrm{BBB}$ were only distributed in the TRGW sample (Table 5). Nucleotide divergence between these composite genotypes was $0.10 \%$ (between ABB-BBB) and $1.46 \%$ (between ABB-CAA) (data not shown). The most parsimonious network inferred from polymorphic 
sites of sequences examined revealed 2 different lineages of composite genotypes perfectly corresponding to specimens from the Gulf of Thailand (I) and Andaman Sea (II), respectively (Figure 6). Nucleotide differences within lineage genotypes (2-4 mutation steps) were lower than those between lineage genotypes ( 8 mutation steps) where an interconnection between the common AAA genotype (lineage I) and BBB (lineage II) required 14 mutation steps.

Table 5. Distribution frequencies of composite single-strand conformational polymorphism genotypes in wild and domesticated stocks of Haliotis asinina using $\mathrm{HaSCAR}_{320}, \mathrm{HaSCAR}_{295}$ and $\mathrm{HaSCAR}_{327}$ sequencecharacterized amplified region (SCAR) markers.

\begin{tabular}{|c|c|c|c|c|c|}
\hline \multirow[t]{2}{*}{ Composite haplotype } & \multicolumn{3}{|c|}{ Wild } & \multicolumn{2}{|c|}{ Domestication } \\
\hline & SAME & CAME & TRGW & CTRGH & CSMaRTH \\
\hline AAA & $16(0.80)$ & $14(0.64)$ & - & $18(0.45)$ & $70(0.74)$ \\
\hline $\mathrm{AAB}$ & - & - & - & $4(0.10)$ & - \\
\hline AAC & $2(0.10)$ & - & - & $7(0.18)$ & $14(0.15)$ \\
\hline $\mathrm{ABB}$ & - & - & $1(0.04)$ & - & - \\
\hline $\mathrm{ABC}$ & - & - & - & $3(0.07)$ & - \\
\hline BAA & - & - & - & - & $2(0.02)$ \\
\hline BAB & - & - & $1(0.04)$ & - & - \\
\hline BAC & - & - & - & - & $1(0.01)$ \\
\hline BBB & - & - & $23(0.92)$ & - & - \\
\hline CAA & $2(0.10)$ & $8(0.36)$ & - & $7(0.18)$ & $7(0.07)$ \\
\hline CAC & - & - & - & $1(0.02)$ & $1(0.01)$ \\
\hline Total & 20 & 22 & 25 & 40 & 95 \\
\hline
\end{tabular}

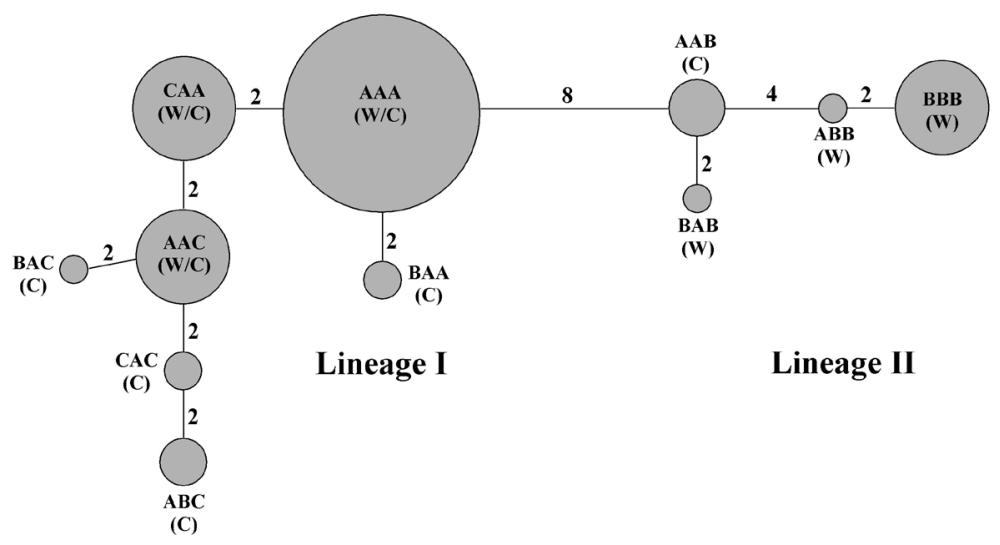

Figure 6. A maximum parsimonious network illustrating genetic relationships between composite single-strand conformational polymorphism (SSCP) genotypes of $\mathrm{HaSCAR}_{320}, \mathrm{HaSCAR}_{295}$ and $\mathrm{HaSCAR}_{327}$. Numbers between pairs of composite SSCP genotypes indicate the number of mutation steps required for their connections. The capital letters in parentheses refer to wild (W) and domesticated (C) specimens, respectively.

Limited genetic diversity was observed in all wild samples. The average polymorphic bands and gene diversity of all primers in TRGW (23.08\% and 0.0847$)$ was slightly lower than that of SAME (30.77\% and 0.0836) but greater than that of CAME (15.38\% and 0.0617). Genetic distance between pairs of wild samples were 0.0154 (SAME and CAME), 1.0473 (TRGW and SAME) and 1.0926 (TRGW and CAME), respectively (Table 6). Genetic het- 
erogeneity was observed between different coastal regions $(\mathrm{P}<0.0001$ for the exact test and $\mathrm{P}<0.001$ for $F_{\mathrm{ST}}$-based statistics, $\left.\theta\right)$ but not within the Gulf of Thailand $(\mathrm{P}>0.05)$ (Table 7).

\begin{tabular}{|c|c|c|c|c|c|}
\hline & SAME & CAME & TRGW & CSMaRTH & CTRGH \\
\hline SAME & 0.0836 & & & & \\
\hline CAME & 0.0154 & 0.0617 & & & \\
\hline TRGW & 1.0473 & 1.0926 & 0.0847 & & \\
\hline CSMaRTH & -0.0005 & 0.0217 & 1.0187 & 0.2322 & \\
\hline CTRGH & 0.0279 & 0.0565 & 0.6951 & 0.0241 & 0.0934 \\
\hline
\end{tabular}

Table 7. Genetic heterogeneity analysis based on the exact test (above diagonal) and $F_{\mathrm{ST}}$ estimate (below diagonal) between pairs of Haliotis asinina samples.

\begin{tabular}{|c|c|c|c|c|c|}
\hline & SAME & CAME & TRGW & CSMaRTH & CTRGH \\
\hline SAME & & $\mathrm{P}=0.9243^{\text {ns }}$ & $\mathrm{P}<0.0001 *$ & $\mathrm{P}=1.0000^{\mathrm{ns}}$ & $\mathrm{P}=0.5125^{\mathrm{ns}}$ \\
\hline CAME & $0.1635^{*}$ & & $\mathrm{P}<0.0001^{*}$ & $\mathrm{P}=0.1461^{\mathrm{ns}}$ & $\mathrm{P}=0.0115^{*}$ \\
\hline TRGW & $0.8759 *$ & $0.8919^{*}$ & & $\mathrm{P}<0.0001^{*}$ & $\mathrm{P}<0.0001^{*}$ \\
\hline CSMaRTH & $-0.0058^{\mathrm{ns}}$ & $0.1826^{*}$ & $0.8641 *$ & & $\mathrm{P}<0.0001^{*}$ \\
\hline CTRGH & $0.1220^{*}$ & $0.2245^{*}$ & $0.7064 *$ & $0.1478^{*}$ & \\
\hline
\end{tabular}

$\mathrm{ns}=$ not significant, $*$ = significant at $\mathrm{P}<0.017$ following the sequential Bonferroni's adjustment (Rice, 1989).

\section{Genetic diversity of domesticated stocks (CTRGH and CSMaRTH) of H. asinina}

Eight composite SSCP genotypes were found in the domesticated samples and only three of which (AAA, AAC and CAA) were observed in wild abalone (CAME and SAME) samples. These composite genotypes were also common genotypes in our domesticated abalone stocks (Table 5). Composite BAA and BAC genotypes were found only in CSMaRTH while $\mathrm{AAB}$ and $\mathrm{ABC}$ were restrictively observed in CTRGH. The appearance of these composite genotypes reflected greater genetic diversity of the domesticated than wild stocks of $H$. asinina in this study (Table 6). Interestingly, composite ABB, BAB and BBB genotypes found in wild abalone from the Andaman Sea and regarded as members of the lineage II, were not found in the domesticated stocks (CTRGH and CSMaRTH) (Table 5 and Figure 6). All individuals of CSMaRTH $(90 / 90 ; 100 \%)$ carried lineage I composite genotypes. Only 4 individuals of CTRGH $(4 / 40,10 \%)$ possessed the AAB genotype, which was parsimoniously recognized as a member of the lineage II genotypes (Figure 6). This indicated that the gene pools of domesticated stocks have been genetically contributed to by almost all brooders from the Gulf of Thailand.

Modest genetic diversity was observed in the domesticated stocks. The average polymorphic bands and gene diversity of all primers in CSMaRTH (23.08\% and 0.0934$)$ were comparable, but those of CTRGH (69.23\% and 0.2322$)$ were greater than those of wild stocks (see above). Limited genetic distance was observed between these and SAME and CAME (-0.0005-0.0565) but large genetic distance was observed when compared with the Andaman Sea sample (TRGW: 0.6951-1.0187; Table 6).

Genetic heterogeneity based on the exact test indicated that CSMaRTH and CTRGH were genetically different $(\mathrm{P}<0.001)$. The gene pool of CSMaRTH was not different from 
wild abalone from the Gulf of Thailand (CAME and SAME; P $>0.05$ ). However, genetic heterogeneity was observed between CTRGH and CAME $(\mathrm{P}<0.017)$ and between both domesticated stocks and TRGW $(\mathrm{P}<0.001)$ (Table 7).

\section{DISCUSSION}

\section{Strong population genetic differentiation of wild $\boldsymbol{H}$. asinina in Thai waters revealed by SSCP analysis of AFLP-derived SCAR markers}

AFLP analysis is useful for a variety of evolutionary, ecological and population genetic studies (Khamnamtong et al., 2006; Zhang et al., 2007; Gruenthal et al., 2007; Gruenthal and Burton, 2008). In this study, AFLP generated a large number of polymorphic fragments in screened $H$. asinina individuals. Some of which were regarded as candidate coastal-specific fragments. However, an AFLP approach is composed of several steps, which are tedious and time consuming, particularly when dealing with large sample sizes. As a result, we did not directly apply this approach for determination of genetic diversity of $H$. asinina in the present study. Instead, we converted AFLPs to SCAR markers. SSCP was further applied for rapid examining sequence polymorphism of the developed SCAR markers initially in geographically different samples and subsequently, in the present generation of our domesticated $H$. asinina stocks.

A total of 11 composite genotypes were generated from all single genotypes found from $\mathrm{HaSCAR}_{320}, \mathrm{HaSCAR}_{295}$ and $\mathrm{HaSCAR}_{327}$. All composite genotypes could be related by at least two mutation steps. No direct intermediate genotypes were observed suggesting that the sample sizes should be increased from 202 individuals used in the present study to identify rare intermediate genotypes between their evolutionary lineages.

Two lineages of composite genotypes were clearly observed. Shared genotypes between abalone from different coastal regions were not found. Distributions of $H$. asinina composite SSCP genotypes clearly indicated the existence of strong intraspecific genetic differentiation within Thai $H$. asinina. The information also suggests that $H$. asinina from the Gulf of Thailand and Andaman Sea may have been colonized by two independent ancestral populations, one from the west, and one from the north.

Recently, genetic variation and population differentiation of the red abalone ( $H$. rufescens) along the California coastline was examined by mitochondrial cytochrome oxidase subunit I (COI) sequence, microsatellites, and AFLP. COI sequences and microsatellite genotypes did not reveal significant genetic divergence among nine geographic samples of H. rufescens. In contrast, AFLP indicated significant divergence between five examined geographic samples in that study ( $\mathrm{P}<0.001)$. However, no population-diagnostic AFLP markers were found in any of the examined geographic samples (Gruenthal et al., 2007).

Non-overlapping composite SSCP genotypes were observed in $H$. asinina from the east and west coasts suggesting strong genetic population structure of this abalone in Thai waters. Molecular markers for identification of geographic origin of abalone populations found in this study can be utilized for identification of seed stocks and distribution and recruitment of abalone larvae, leading to increased efficiency in fishery management of local $H$. asinina stocks in Thailand (Klinbunga et al., 2003).

Shephred and Brown (1993) predicted that microgeographic population differentiation within each abalone species probably occurred due to its short planktonic larval stages 
and limited dispersal ability. Accordingly, intraspecific genetic differentiation of abalone may be found within the scale of a few kilometers. Jarayabhand et al. (2002) examined genetic diversity in $H$. ovina originating from Chon Buri $(\mathrm{N}=24)$ and Rayong $(\mathrm{N}=18)$ located in the Gulf of Thailand and Trang $(\mathrm{N}=18)$ and Phangnga $(\mathrm{N}=11)$ located in the Andaman Sea by PCR-RFLP of $16 S$ rDNA (approximately 580 bp in length) with BamHI, EcoRI, HaeIII, and AluI. Three composite haplotypes (ABBB, AAAB and AABB) were found across overall specimens. No overlapping haplotypes were found between $H$. ovina originating from the east (ABBB) and west (AAAB and AABB) coasts of peninsular Thailand.

In contrast, a lack of genetic differentiation of $H$. asinina in Thai waters was previously reported based on restriction analysis of $16 \mathrm{~S}$ and $18 \mathrm{~S} \mathrm{rDNAs}$ (Klinbunga et al., 2003). At a larger geographic level, the phylogeographical structure of $H$. asinina collected from 16 geographically discrete sites throughout the Indo-Malay Archipelagoes, and eastern Indian and western Pacific Oceans was examined by sequence polymorphism of the mitochondrial cytochrome oxidase subunit II (COII) gene segment (482 bp, $\mathrm{N}=206$ ). Limited sequence divergence among geographic samples ranged from $1.1 \%$ between Indian and Indo-Malay sites and $3.7 \%$ between Indian and Pacific sites and 3.0\% between Pacific and Indo-Malay sites. No finer scale phylogeographical structure was resolved within the respective geographical regions (Imron et al., 2007). Subsequently, genetic heterogeneity of $H$. asinina in Thai waters was reported based on polymorphism of three microsatellite loci (CUHas2, CUHas 3 and CUHas8). Relatively high genetic diversity and strong population differentiation in $H$. asinina was found between abalone from the Gulf of Thailand (Samet Island and Cambodia) and Andaman Sea (Talibong Island) $\left(F_{\mathrm{ST}}=0.1977-0.2111, \mathrm{P}<0.0001\right.$; Tang et al., 2004).

Like results from microsatellites, genetic heterogeneity analysis and $F_{\mathrm{ST}}$-based statistics revealed significant genetic differentiation between abalone from different coastal regions ( $\mathrm{P}<0.0001$ for the exact test and $F_{\mathrm{ST}}=0.8759-0.8919, \mathrm{P}<0.001$, respectively). This consistently confirmed that the gene pool of Thai $H$. asinina was not panmictic but clearly fragmented into two genetic populations: the Gulf of Thailand and the Andaman Sea, and $H$. asinina is a low gene flow species.

Similar circumstances on the contrary of population differentiation patterns inferred from different genetic markers, were also reported in the California black abalone (H. cracherodii) sampled from the central California coast and four islands in the Southern California Bight. COI sequence polymorphism $(\mathrm{N}=238)$ between pairs of examined populations was not statistically significant after adjustment by a sequential Bonferroni's correction. In contrast, microsatellite (Hka28) and AFLP data (3 primer combinations) showed significant divergence in multiple pairwise population comparisons and indicated restricted dispersal in $\mathrm{H}$. cracherodii (Gruenthal and Burton, 2008).

Genetic differentiation of $H$. asinina could be explained by a major physical barrier as the main current in the Straits of Malacca, which flows from south to north throughout the year (Dale, 1956). This should have affected the gene flow levels of $H$. asinina in Thai waters. In addition, $H$. asinina needs to settle on specific species of coralline algae after 3-4 days in the planktonic larval stage. The failure to contact a suitable alga within approximately 10 days of hatching usually results in death. These life cycle characteristics suggest a limited dispersal level of $H$. asinina (Imron et al., 2007).

Considering the life history, larval development, and dispersing ability of $H$. asinina, contradictory results on patterns of genetic differentiation of natural $H$. asinina based on anal- 
ysis of mitochondrial $16 S$ rDNA (panmictic gene pool; Jarayabhand et al., 2002; Klinbunga et al., 2003) and microsatellites and nuclear $\mathrm{HaSCAR}_{320}, \mathrm{HaSCAR}_{295}$ and $\mathrm{HaSCAR}_{327}$ (fragmented gene pool; Tang et al., 2004 and this study) are likely to have resulted from female founder effects rather than biased female gene flow in this species.

Therefore, the assumption of a large single-breeding stock in Thai $H$. asinina previously reported based on $16 \mathrm{~S}$ and $18 \mathrm{~S}$ rDNA polymorphisms must be changed (Ward and Grewe, 1994; Klinbunga et al., 2003). Geographically and genetically different populations of Thai $H$. asinina should be recognized as different stocks and managed separately by fishery managers and government organizations (Carvalho and Hauser, 1994; Conover et al., 2006).

\section{Genetic diversity and stock origin of domesticated $H$. asinina}

The higher genetic diversity of domesticated stock (CTRGH and CSMaRTH) over wild samples based on polymorphism of $\mathrm{HaSCAR}_{320}, \mathrm{HaSCAR}_{295}$ and $\mathrm{HaSCAR}_{327}$ suggests that inbreeding is not a major concern for the established stocks at present. This status is likely the result of the use of a large number of founders originating from various geographic locations in Thai waters at the beginning of our breeding program. Genotype distribution patterns of $\mathrm{HaSCAR}_{320}, \mathrm{HaSCAR}_{295}$ and $\mathrm{HaSCAR}_{327}$ clearly illustrated that the gene pools of domesticated stocks of $H$. asinina have been generally maintained by progeny bred from the east coast rather than those from the west coast founders. This obviously revealed greater survival rates and reflected the possible better adaptability of $H$. asinina from the east (Gulf of Thailand) than the west (Andaman Sea) coasts to the aquacultural conditions. Nevertheless, this finding may be biased by the inclusion of a larger number of founders from the east than the west coast of Thai waters (approximately 70:30) at the beginning of our breeding program.

Significant genetic heterogeneity between CSMaRTH and CTRGH (domesticated stocks) and between CTRGH and wild CAME (east) were observed. Since both domesticated stocks were bred from the same group of founders and offspring were cultured separately in the hatcheries located in different geographic areas (CSMaRTH at SMaRT and CTRGH in Trang province), there is the chance of randomly high mortality rates in cultured abalone. Accordingly, $\mathrm{HaSCAR}_{320}, \mathrm{HaSCAR}_{295}$ and $\mathrm{HaSCAR}_{327}$ should be further used to confirm whether mixed progeny from multiple parents exhibit different survival rates under the same cultivated conditions by using a new stock established from approximately equal numbers of founders from both coastal regions.

In this study, SCAR markers were successfully developed. Polymorphic SSCP patterns of these markers could be further applied to assist genetic improvement and breeding programs of $H$. asinina; for example, determination of the correlation between genotypes and survival rates after settlement of larvae. In addition, $\mathrm{HaSCAR}_{320}, \mathrm{HaSCAR}_{295}$ and $\mathrm{HaSCAR}_{327}$ markers may be used to monitor effects of aquacultural activity on levels of population differentiation of natural $H$. asinina in Thai waters.

\section{ACKNOWLEDGMENTS}

We would like to thank the National Center for Genetic Engineering and Biotechnology (BIOTEC), Thailand, for providing facilities required for the experiments. 


\section{REFERENCES}

Allendorf FW and Ryman N (1987). Genetic Management of Hatchery Stocks. In: Population Genetics and Fishery Management (Ryman N and Utter F, eds.). University of Washington, Seattle, 141-159.

Altschul SF, Gish W, Miller W, Myers EW, et al. (1990). Basic local alignment search tool. J. Mol. Biol. 215: 403-410.

Carvalho GR and Hauser L (1994). Molecular genetics and the stock concept in fisheries. Rev. Fish Biol. Fish. 4: 326-350.

Conover DO, Clarke LM, Munch SB and Wagner GN (2006). Spatial and temporal scales of adaptive divergence in marine fishes and the implications for conservation. J. Fish Biol. 69: 21-47.

Cruz P, Ibarra AM, Mejia-Ruiz H, Gaffney PM, et al. (2004). Genetic variability assessed by microsatellites in a breeding program of Pacific white shrimp (Litopenaeus vannamei). Mar. Biotechnol. 6: 157-164.

Dale WL (1956). Wind and drift currents in the South China Sea. Malays. J. Trop. Geogr. 8: 1-31.

Evans B, Conod N and Elliott NG (2001). Evaluation of microsatellite primer conservation in abalone. J. Shellfish Res. 20: $1065-1070$.

Geiger DL (2000). Distribution and biogeography of the Haliotidae (Gastropoda: Vetigastropoda) world-wide. Boll. Malacol. 35: 57-120.

Gordon HR and Cook PA (2004). World abalone fisheries and aquaculture update: supply and market dynamics. $J$. Shellfish Res. 23: 935-939.

Gruenthal KM and Burton RS (2008). Genetic structure of natural populations of the California black abalone (Haliotis cracherodii Leach, 1814), a candidate for endangered species status. J. Exp. Mar. Biol. Ecol. 355: 47-58.

Gruenthal KM, Acheson LK and Burton RS (2007). Genetic structure of natural populations of California red abalone (Haliotis rufescens) using multiple genetic markers. Mar. Biol. 152: 1237-1248.

Imron JB, Hale P, Degnan BM and Degnan SM (2007). Pleistocene isolation and recent gene flow in Haliotis asinina, an Indo-Pacific vetigastropod with limited dispersal capacity. Mol. Ecol. 16: 289-304.

Jarayabhand P and Paphavasit N (1996). A review of the culture of tropical abalone with special reference to Thailand. Aquaculture 140: 159-168.

Jarayabhand P, Pripue P, Khamnamtong N and Klinbunga S (2002). Identification of species-diagnostic markers of abalone in Thailand using PCR-RFLP of 16S rDNA. Fisheries Sci. 68 (Suppl A): 1091-1094.

Khamnamtong B, Klinbunga S and Menasveta P (2005). Species identification of five penaeid shrimps using PCR-RFLP and SSCP analyses of 16S ribosomal DNA. J. Biochem. Mol. Biol. 38: 491-499.

Khamnamtong B, Thumrungtanakit S, Klinbunga S, Aoki T, et al. (2006). Identification of sex-specific expression markers in the giant tiger shrimp (Penaeus monodon). J. Biochem. Mol. Biol. 39: 37-45.

Kimura M (1980). A simple method for estimating evolutionary rates of base substitutions through comparative studies of nucleotide sequences. J. Mol. Evol. 16: 111-120.

Klinbunga S, Pripue P, Khamnamtong N, Puanglarp N, et al. (2003). Genetic diversity and molecular markers of the tropical abalone (Haliotis asinina) in Thailand. Mar. Biotechnol. 5: 505-517.

Klinbunga S, Amparyup P, Leelatanawit R, Tassanakajon A, et al. (2004). Species identification of the tropical abalone (Haliotis asinina, Haliotis ovina, and Haliotis varia) in Thailand using RAPD and SCAR markers. J. Biochem. Mol. Biol. 37: 213-222.

Klinbunga S, Preechaphol R, Thumrungtanakit S, Leelatanawit R, et al. (2006). Genetic diversity of the giant tiger shrimp (Penaeus monodon) in Thailand revealed by PCR-SSCP of polymorphic EST-derived markers. Biochem. Genet. 44: 222-236.

Klinbunga S, Khetpu K, Khamnamtong B and Menasveta P (2007). Development of a species-diagnostic SCAR marker of the blue swimming crab (Portunus pelagicus). Biochem. Genet. 45: 755-760.

Li Z, Li J, Wang Q, He Y, et al. (2006). The effects of selective breeding on the genetic structure of shrimp Fenneropenaeus chinensis populations. Aquaculture 258: 278-282.

Lui ZJ and Cordes JF (2004). DNA marker technologies and their applications in aquaculture genetics. Aquaculture 238: 1-37.

Miller MP (1997). Tools for population genetic analyses TFPGA 1.3: a window program for the analysis of allozyme and molecular population genetic data. Northern Arizona University, Flagstaff.

Nei M (1978). Estimation of average heterozygosity and genetic distance from a small number of individuals. Genetics 89: $583-590$

Nei M (1987). Molecular Evolutionary Genetics. Columbia University Press, New York.

Orita M, Iwahana H, Kanazawa H, Hayashi K, et al. (1989). Detection of polymorphisms of human DNA by gel electrophoresis as single-strand conformation polymorphisms. Proc. Natl. Acad. Sci U. S. A. 86: 2766-2770.

Rice WR (1989). Analyzing tables of statistical tests. Evolution 43: 223-225.

Sambrook J and Russell DW (2001). Molecular Cloning: A Laboratory Manual. 3rd edn. Cold Spring Harbor Laboratory Press, New York. 
Selvamani MJ, Degnan SM, Paetkau D and Degnan BM (2000). Highly polymorphic microsatellite loci in the Heron Reef population of the tropical abalone Haliotis asinina. Mol. Ecol. 9: 1184-1186.

Shephred SA and Brown LD (1993). What is an abalone stock: implications for the role of refugia in conservation. Can. J. Fish. Aquat. Sci. 50: 2001-2009.

Singhagraiwan T and Doi M (1993). Seed Production and Culture of a Tropical Abalone Haliotis asinina Linne. The Research Project of Fishery Resource Development in the Kingdom of Thailand. Ministry of Agriculture and Cooperatives, Thailand.

Tang S, Tassanakajon A, Klinbunga S, Jarayabhand P, et al. (2004). Population structure of tropical abalone (Haliotis asinina) in coastal waters of Thailand determined using microsatellite markers. Mar. Biotechnol. 6: 604-611.

Vos P, Hogers R, Bleeker M, Reijans M, et al. (1995). AFLP: a new technique for DNA fingerprinting. Nucleic Acids Res. 23: 4407-4414

Ward RD and Grewe PM (1994). Appraisal of molecular genetic techniques in fisheries. Rev. Fish Biol. Fisheries 4: 300-325

Weir BS and Cockerham CC (1984). Estimating F-statistics for the analysis of population structure. Evolution 38: 1358-1370.

Williams JG, Kubelik AR, Livak KJ, Rafalski JA, et al. (1990). DNA polymorphisms amplified by arbitrary primers are useful as genetic markers. Nucleic Acids Res. 18: 6531-6535.

Yu DH and Chu KH (2006). Low genetic differentiation among widely separated populations of the pearl oyster Pinctada fucata as revealed by AFLP. J. Exp. Mar. Biol. Ecol. 333: 140-146.

Zhang J, Wang H and Cai Z (2007). The application of DGGE and AFLP-derived SCAR for discrimination between Atlantic salmon (Salmo salar) and rainbow trout (Oncorhynchus mykiss). Food Cont. 18: 672-676.

Zhao C, Li Q and Kong L (2009). Inheritance of AFLP markers and their use for genetic diversity analysis in wild and farmed scallop (Chlamys farreri). Aquaculture 287: 67-74. 